\title{
Human insulin: study of safety and efficacy in man
}

\author{
D R OWENS, M K JONES, T M HAYES, L G HEDING, K G M M ALBERTI, P D HOME, \\ J M BURRIN, R G NEWCOMBE
}

\begin{abstract}
The safety and efficacy of a new highly purified neutral soluble human insulin produced by conversion of porcine insulin was compared with a highly purified neutral soluble porcine insulin in six normal men. The insulins were administered by subcutaneous injection at a dose of $0.075 \mathrm{U} / \mathrm{kg}$ body weight. Somatostatin was infused during the experiment to suppress endogenous insulin secretion. No difference was found in the plasma glucose, insulin, or metabolite responses. Thus the potency, onset, and duration of effect were identical with the two insulins. No short-term side effects to either insulin were observed.

Highly purified, semi-synthetic human insulin offers a safe and effective means to explore the possible advantages of homologous human insulin in the management of diabetes mellitus.
\end{abstract}

\section{Introduction}

Both porcine and bovine insulins are used to treat diabetes mellitus. These insulins differ in their structure from human insulin by one and three amino-acids respectively. ${ }^{1}$ We therefore need to know whether human insulin has any advantages over the other insulins in the treatment of diabetes.

Human insulin may be prepared from human pancreas, ${ }^{2}$ by total chemical synthesis, ${ }^{3}$ by semi-synthesis from porcine insulin, ${ }^{45}$ and by recombinant DNA technology using Escherichia coli. ${ }^{6}$ Pancreatic human insulin has been available for some time, primarily for allergy testing in diabetics ${ }^{7}$; and fully synthetic human insulin has been used for only short-term treatment of a few patients. ${ }^{8} \mathrm{E}$ coli human insulin has recently been compared with porcine insulin in healthy men. ${ }^{9}$

We decided to compare the plasma glucose, insulin, and intermediary metabolite responses to subcutaneously administered highly purified semi-synthetic human and porcine neutral soluble insulins in normal men. Somatostatin was infused intravenously to suppress endogenous beta-cell secretion ${ }^{10}{ }^{11}$ and allow the plasma insulin profiles to represent the absorption and clearance of the administered insulins more precisely.

Welsh National School of Medicine, Cardiff CF4 4XW

D R OWENS, $M B, C H B$, honorary lecturer in medicine

$M K$ JONES, MRCP, senior registrar in medicine

$T M$ HAYES, FRCP, senior lecturer and consultant physician

R G NEWCOMBE, MA, PHD, lecturer in medical statistics

Novo Research Institute, Novo Alle, DK-2880 Bagsvaerd, Denmark L G HEDING, PHD, head of medical department

Royal Victoria Infirmary, Newcastle upon Tyne NE1 4LP

P D HOME, DPHIL, MRCP, research associate, department of clinical biochemistry and metabolic medicine

K G M M ALBERTI, DPHIL, FRCP, professor of clinical biochemistry and metabolic medicine

J M BURRIN, PHD, research associate, department of clinical biochemistry and metabolic medicine

\section{Subjects, materials, and methods}

We studied six healthy men aged 27-38 years who were within $10 \%$ of ideal body weight ${ }^{12}$ and had no family history of diabetes mellitus. All gave informed consent, and the study was approved by the local ethical committee. None of the subjects had received insulin before, and none had a history of atopy or allergy or was taking any medication at the time of the study.

The neutral soluble human insulin was manufactured by Novo के Industri A/S, Copenhagen, to monocomponent specifications. The $\vec{O}$ process for producing semi-synthetic human insulin employs porcine $\overrightarrow{\vec{J}}$ insulin as the basic raw material, which is converted into human $\omega$ insulin by replacing a single amino-acid in the B chain (B30 alanine) $\partial$ with threonine by an enzymatically catalysed process that preserves 3 the disulphide bonds. The crude product is then purified to monocomponent specifications by chromatographic procedures. The equivalent porcine insulin, Actrapid MC, was used as the comparative of insulin preparation, and the diluent contained in Actrapid MC was $N$ used for the control studies.

Each volunteer was studied on three separate occasions at weekly $\vec{N}$ intervals. At 0800 , after a 10 -hour fast (time $-120 \mathrm{~min}$ ), a cannula was inserted into an antecubital vein kept patent by a slow-running infusion of saline $(0.154 \mathrm{mmol} / 1 ; 0.9 \mathrm{mg} / 100 \mathrm{ml})$. Blood samples were taken via a three-way tap attached to the intravenous cannula. A $\vec{\infty}$ second intravenous cannula was sited in the opposite antecubital vein, $D$ and 30 minutes later (time $-90 \mathrm{~min}$ ) a somatostatin infusion (100 $\mu \mathrm{g} / \mathrm{h}$ ) was begun using an infusion pump and continued throughout.

Human insulin, porcine insulin, and diluent were administered at $\vec{\emptyset}$ random by subcutaneous bolus injection (time $0 \mathrm{~min}$ ) using a Plastipak. SFP $1 \mathrm{ml}$ syringe. Insulins were given at a dose of $0.075 \mathrm{U} / \mathrm{kg}$ body weight. The injection site was $10 \mathrm{~cm}$ from the umbilicus towards the anterior superior iliac spine.

Venous blood samples were obtained at $-120,-105,-90,-60$, $-30,0,10,20,30,40,50,60$, and every 30 minutes up to 360 minutes. Aliquots were taken into heparin for measurement of immuno- $\varrho$ reactive insulin (IRI) ${ }^{13}$ and C-peptide ${ }^{14}$ concentrations, into fluoride $\overrightarrow{\vec{P}}$ for plasma glucose determination (hexokinase), and $(0.5 \mathrm{ml})$ into $2 \mathrm{ml}$ $3 \%(w / v)$ perchloric acid for estimation of lactate, alanine, and 3-hydroxybutyrate concentrations. ${ }^{15}$ Samples were centrifuged within five minutes and the supernatants stored at $-20^{\circ} \mathrm{C}$ until assay. The detection limit of immunoreactive insulin was $0.0062 \mathrm{nmol} / \mathrm{l}(0.036 \mathrm{ng} /$ $\mathrm{ml}$ ) and the sensitivity (SD within-assay) $0.0025 \mathrm{nmol} / 1(0.015 \mathrm{ng} / \mathrm{ml})$. The detection limit of C-peptide was $0.01 \mathrm{nmol} / 1(0.03 \mathrm{ng} / \mathrm{ml})$ and the sensitivity $0.004 \mathrm{nmol} / 1(0.012 \mathrm{ng} / \mathrm{ml})$.

For each individual subject all samples were measured in one assay. Human and porcine insulins reacted identically in the insulin radioimmunoassay.

Statistical-Results are expressed as means \pm SE except where $\stackrel{\circ}{\frac{1}{3}}$ stated otherwise. Concentrations of 3-hydroxybutyrate were $\log N$ transformed to normalise distribution. ${ }^{16}$ Individual pairs of treatments were compared using paired analysis of variance with time 0 as a covariate. The computer program used was the Statistical Package for the Social Sciences.

\section{Results}

No adverse reactions to either insulin were observed. Figure $1 \stackrel{\mathscr{D}}{\rightarrow}$ shows the plasma glucose, C-peptide, and immunoreactive insulin 0 values in the six subjects when infused with somatostatin and given $\bar{O}$ subcutaneous boluses of diluent (control preparation), human insulin, $\vec{D}$ and porcine insulin. Plasma glucose concentrations were similar in $\frac{\rho}{\mathbb{P}}$ the three study periods before subcutaneous injection. During the $\varrho$ period preceding injection of the comparative preparations somato-

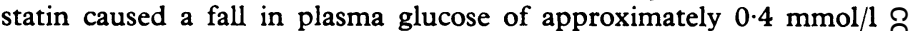
$(7 \cdot 2 \mathrm{mg} / 100 \mathrm{ml})$. In the control study there was then a rise to $5 \cdot 0-5 \cdot 8$ 응 $\mathrm{mmol} / 1(90-105 \mathrm{mg} / 100 \mathrm{ml})$ from time 0 to the end of the study. Thirty minutes after administration of each insulin the plasma glucose value showed a prompt fall, reaching a nadir of about $3.0 \mathrm{mmol} / \mathrm{l}$ 
$(54 \mathrm{mg} / 100 \mathrm{ml}$ ) between 90 and 150 minutes and remaining about 1.5 $\mathrm{mmol} / 1$ lower than the control value at six hours. From 30 minutes after injection the glucose concentrations during the two insulin studies were significantly different from control values $(0.005>p>$ 0.001). There was no significant difference between the glucose responses to human and porcine insulins at any time (figs 1 and 2).

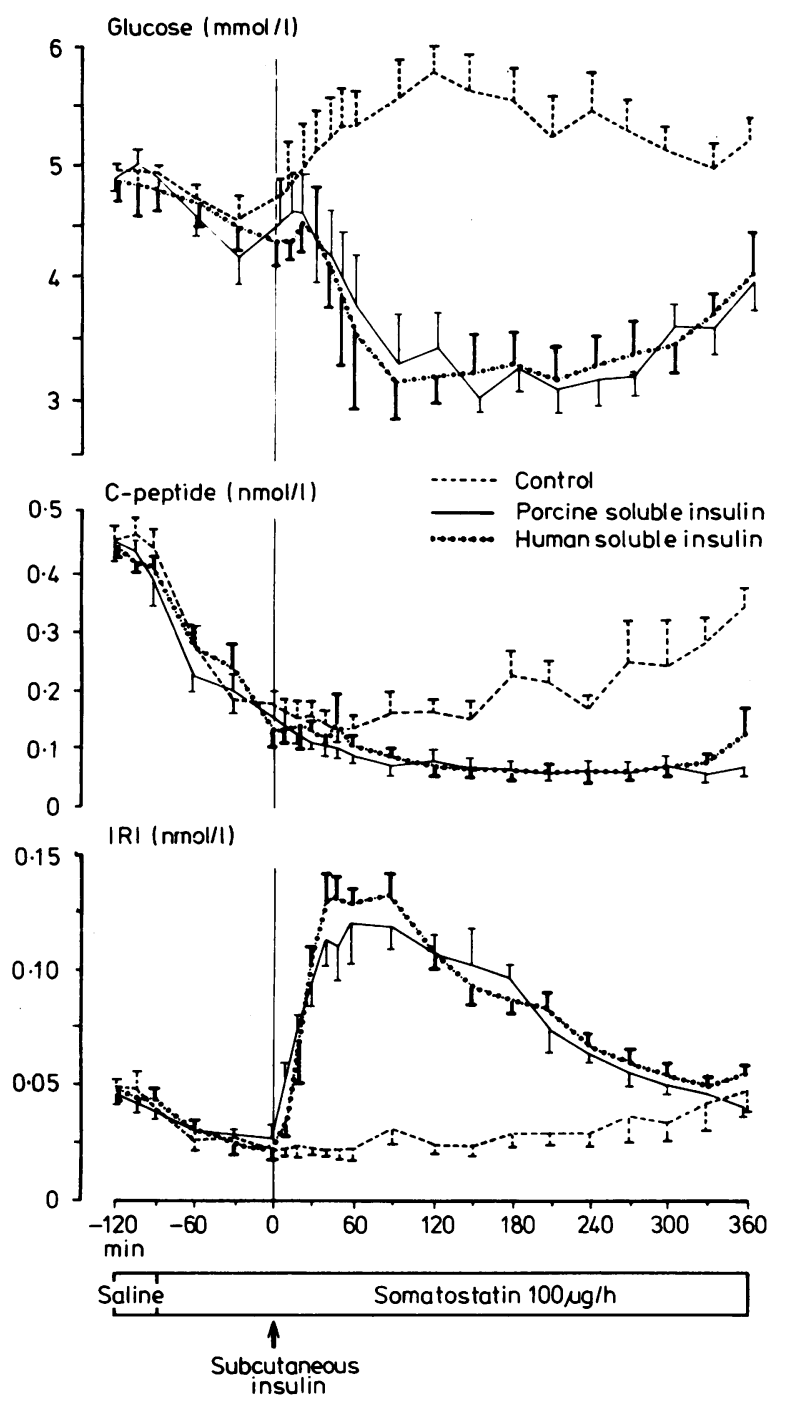

FIG 1-Effect of highly purified human and porcine insulins on plasma glucose. insulin (IRI), and C-peptide concentrations (mean \pm SEM) in six normal men. Somatostatin infused from -90 to $+360 \mathrm{~min}$. Insulin $(0.075$ $\mathrm{U} / \mathbf{k g}$ ) or diluent (control) given subcutaneously at time 0 .

Conversion: SI to traditional units-Glucose: $1 \mathrm{mmol} / 1 \approx 18 \mathrm{mg} / 100 \mathrm{ml}$. C-peptide: $1 \mathrm{nmol} / 1 \approx 3.02 \mathrm{ng} / \mathrm{ml}$. IRI: $1 \mathrm{nmol} / 1 \approx 5.8 \mathrm{ng} / \mathrm{ml}$.

The mean plasma C-peptide concentration decreased from 0.45 $\mathrm{nmol} / 1$ to $0.15 \mathrm{nmol} / 1(1.36 \mathrm{ng} / \mathrm{ml}$ to $0.45 \mathrm{ng} / \mathrm{ml})$ during the first 90 minutes of somatostatin infusion (fig 1). After injection of diluent C-peptide concentrations tended to rise after two hours, reaching roughly $75 \%$ of preinfusion values by the end of the experiment. C-peptide concentrations after insulin were significantly lower than after diluent-from 30 minutes after porcine insulin and from 120 minutes after human insulin. From two to five and a half hours after both insulins $C$-peptide values remained between 0.04 and 0.07 $\mathrm{nmol} / 1(0.12$ and $0.21 \mathrm{ng} / \mathrm{ml}$ ) (fig 1). During the experiment no difference was seen between the values after human and porcine insulins (fig 2).

Initial plasma insulin concentrations of approximately $0.045 \mathrm{nmol} / \mathrm{l}$ $(0.26 \mathrm{ng} / \mathrm{ml})$ fell to $0.024 \mathrm{nmol} / 1(0.14 \mathrm{ng} / \mathrm{ml})$ after 90 minutes of somatostatin. Values remained low after diluent, rising slightly at four hours. Subcutaneous injection of human insulin led to a rapid rise in plasma insulin concentrations, reaching a peak after 40 to 90 minutes and being significantly higher than control values from 10 minutes after injection (fig 1). After porcine insulin peak plasma insulin concentrations were reached 40 to 120 minutes after injection, values again being significantly higher than control values from 10 minutes. Peak insulin concentrations after the human and porcine insulins were $0.13 \pm 0.02 \mathrm{nmol} / 1(0.75 \pm 0.12 \mathrm{ng} / \mathrm{ml})$ at 90 minutes and $0.12 \pm 0.03$ $\mathrm{nmol} / \mathrm{l}(0 \cdot 70 \pm 0 \cdot 17 \mathrm{ng} / \mathrm{ml})$ at 60 minutes, respectively. A significant difference in insulin values was observed only at six hours, with a higher concentration $(p<0.05)$ after human insulin (figs 1 and 2$)$.

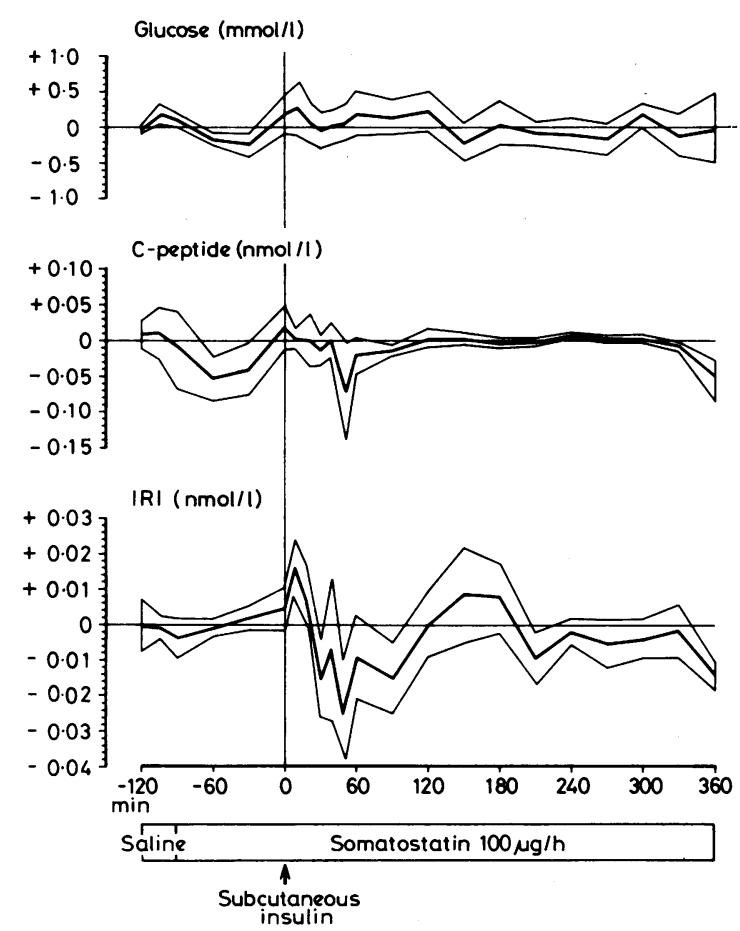

FIG 2-Comparison of effect of human and porcine insulins on plasma glucose, insulin (IRI), and C-peptide concentrations (mean \pm SEM) in six normal men. Somatostatin infused from -90 to $+360 \mathrm{~min}$. Insulin $(0.075$ $\mathrm{U} / \mathrm{kg}$ ) or diluent (control) given subcutaneously at time 0 . (Results shown as means of differences between responses to two insulins (porcine minus human) for six subjects. Value of 0 implies no difference in response. Outer lines represent \pm 1 SE of mean difference.)

Conversion: SI to traditional units-Glucose: $1 \mathrm{mmol} / 1 \approx 18 \mathrm{mg} / 100 \mathrm{ml}$. C-peptide : $1 \mathrm{nmol} / 1 \approx 3.02 \mathrm{ng} / \mathrm{ml}$. IRI: $1 \mathrm{nmol} / 1 \approx 5.8 \mathrm{ng} / \mathrm{ml}$.

There was considerable intraindividual and interindividual variation in intermediary metabolite values. In general, values rose during somatostatin infusion, before insulin injection. After diluent 3hydroxybutyrate concentrations tended to rise, whereas after both insulins concentrations promptly fell, reaching a nadir at about three hours (table); there was no consistent difference after either insulin. Blood glycerol concentrations also rose before administration of the comparative insulin preparations. After porcine and human insulins the values quickly fell, reaching a nadir at 40-90 minutes and 60-180 minutes respectively. No pronounced posthypoglycaemic rise was observed, however, as was seen for 3-hydroxybutyrate (table).

Metabolite values in normal men given highly purified human and porcine insulins $(n=6)$

\begin{tabular}{|c|c|c|c|c|}
\hline & \multicolumn{2}{|c|}{ 3-Hydroxybutyrate ( $\mathrm{mmol} / \mathrm{l})$} & \multicolumn{2}{|c|}{ Glycerol (mmol/l) } \\
\hline & Porcine & Human & Porcine & Human \\
\hline $\begin{array}{ll}\text { Basal } & \begin{array}{l}\text { Mean } \\
\text { Range }\end{array} \\
\text { Preinjection } & \left\{\begin{array}{l}\text { Mean } \\
\text { Range }\end{array}\right. \\
\text { Nadir* } & \begin{array}{l}\text { Mean } \\
\text { Range }\end{array} \\
\text { Mean } \\
\text { Range }\end{array}$ & $\begin{array}{c}0.020 \\
0.005-0.055 \\
0.170 \\
0.025-0.390 \\
0.020 \\
0.005-0.050 \\
0.395 \\
0.045-1.060\end{array}$ & $\begin{array}{c}0 \cdot 065 \\
0.020-0 \cdot 175 \\
0 \cdot 305 \\
0.045-0 \cdot 735 \\
0 \cdot 075 \\
0.020-0 \cdot 20 \\
0 \cdot 370 \\
0.080-0 \cdot 615\end{array}$ & $\begin{array}{c}0 \cdot 045 \\
0.005-0 \cdot 085 \\
0 \cdot 115 \\
0.050-0 \cdot 165 \\
0 \cdot 045 \\
0.020-0.090 \\
0 \cdot 115 \\
0.075-0 \cdot 170\end{array}$ & $\begin{array}{c}0.088 \\
0.010-0.225 \\
0 \cdot 185 \\
0.130-0.325 \\
0.055 \\
0.030-0.085 \\
0 \cdot 095 \\
0.055-0.140\end{array}$ \\
\hline
\end{tabular}

*3-Hydroxybutyrate: porcine insulin 150-180 min, human insulin $180 \mathrm{~min}$; glycerol : porcine insulin 49-90 min, human insulin $60-180 \mathrm{~min}$. Conversion: SI to traditional units-
$\mathrm{ml}$. Glycerol: $1 \mathrm{mmol} / 1 \approx 9 \cdot 2 \mathrm{mg} / 100 \mathrm{ml}$. 


\section{Discussion}

Both insulins were well tolerated, and no adverse effects were observed. No differences were found between human and porcine insulin in their effect on blood glucose, insulin, Cpeptide, and intermediary metabolite concentrations.

The experimental model used to assess the response to human insulin included a low-dose $(100 \mu \mathrm{g} / \mathrm{h})$ somatostatin infusion to suppress endogenous insulin secretion. ${ }^{10}$ The very low Cpeptide values show that suppression was achieved (fig 1). C-peptide values were lower after insulin injection than after diluent, suggesting either that both insulins suppressed insulin secretion direct or, more likely, that endogenous insulin secretion was additionally decreased by the accompanying hypoglycaemia. Using somatostatin allowed us to compare the plasma insulin profiles. After subcutaneous injection insulin concentrations increased significantly from 10 minutes and reached a plateau at 40 to 120 minutes. The two insulins produced profiles suggesting similar rates of absorption and local and systemic clearance. This combined with the identical effects on blood glucose shows that within the limits of the experimental protocol no distinction could be drawn between the two insulins. No firm physiological conclusions were possible, since somatostatin inhibits the secretion of other hormones ${ }^{17}$ and, more important, decreases splanchnic blood flow, ${ }^{18}$ which may slow insulin degradation. The comparative results, however, remain valid. Keen et al, ${ }^{9}$ using $E$ coli-derived human insulin in normal men, also failed to detect any real differences between human and porcine insulins but did not measure insulin concentrations.

The human insulin used in our study was made with porcine insulin as the starting material. In view of possible shortages of insulin derived from conventional sources-namely, bovine and especially porcine pancreas ${ }^{19}$-bacterially produced insulin offers an attractive alternative. Major long-term studies, however, are required to prove that this insulin is totally free of $E$ coli-derived trace contaminants.

We have shown that the hypoglycaemic potency, timing of effect, and short-term safety of human insulin is similar to an equivalent pharmaceutical formulation of a currently available, highly purified porcine insulin. This human insulin therefore provides the opportunity to explore the possible benefits of homologous insulin for diabetes mellitus.

This study was conducted with technical help from Sister A J Rochester (clinical investigations unit, WNSM); Miss E J Ashley and Miss R Fox (medical students, WNSM); Mrs Marianne Heyden, Bente Hansen, Lisbet Pederson, and Birgit Jensen (NRI); and the department of medical biochemistry (WNSM). We are grateful to Professor R Hall (WNSM) and Dr J Schlichtkrull (NRI) for con- structive criticism and advice, and to Mr A Simpson for the illustra- $\square$ tions.

Requests for reprints should be sent to Dr D R Owens.

\section{References}

1 Nicol DSHW, Smith LF. Amino acid sequence of human insulin. Nature 1960;187:483-5.

${ }^{2}$ Mirsky IA, Jinks R, Perisutti G. The isolation and crystallisation of human insulin. $\mathcal{f}$ Clin Invest $1963 ; 42: 1869-72$

${ }^{3}$ Sieber von $\mathrm{P}$, Kamber B, Hartmann A, Jöhl A, Riniker B, Rittel W. Totalsynthese von humaninsulin unter gesielter bildung der disulfid- $\overrightarrow{\vec{D}}$ bindungen. Helvetica Chimica Acta 1974;57:2617-21.

${ }^{4}$ Morihara K, Oka T, Tsuzuki H. Semi-synthesis of human insulin by trypsin catalysed replacement of Ala-B30 by $\mathrm{Thr}$ in porcine insulin. 음 Nature 1979;280:412-3.

${ }^{5}$ Gattner HG, Danho W, Naithani VK. Enzyme-catalysed semi-synthesis $\frac{5}{\widehat{D}}$ with insulin derivatives. In: Proceedings of second international insulin $\mathbb{D}$ symposium, Aachen, Germany, September 1970. Berlin: Walter de Gruyter, 1980:117-23.

${ }^{6}$ Chance RE, Kroeff EP, Hoffmann JA. Chemical, physical and biological $\overrightarrow{0}$ properties of recombinant human insulin. In : FDA conference on insulin and growth hormone, $N I H, 1980$. (In press.)

7 Kreines K. The use of various insulins in insulin allergy. Arch Intern Med $1965 ; 116: 167-71$.

8 Teuscher A. Die, biologische wirkung von voll synthetischem humanem insulin bei patienten mit Diabetes Mellitus. Schweiz Med Wochenschrĩ $1979 ; 109: 743-7$.

${ }^{9}$ Keen H, Pickup JC, Billous RW, et al. Human insulin produced by recombinant DNA technology: safety and hypoglycaemic potency in healthy men. Lancet 1980 ;ii:398-401.

10 Alberti KGMM, Christensen SE, Iversen J, et al. Inhibition of insulin $\rightarrow$ secretion by somatostatin. Lancet 1973 ;ii:1299-301.

11 Home PD, Pickup JC, Keen H, Alberti KGMM. Continuous subcutaneous insulin infusion. Comparison of plasma insulin profiles after $\mathrm{O}$ infusion or bolus injection of the mealtime dose. Metabolism (in press).

12 Metropolitan Life Insurance Company. Statistics bulletin. New York, $\vec{\infty}$ $1960 ; 41: 6$ (Feb), 1 (Mar).

13 Heding LG. Determination of total serum insulin (IRI) in insulin-treated diabetic patients. Diabetologia $1972 ; 8: 260-6$.

14 Heding LG. Radioimmunological determination of human C-peptide in $\overrightarrow{0}$ serum. Diabetologia 1975;11:541-8.

15 Lloyd B, Burrin J, Smythe P, Alberti KGMM. Enzymatic, fluorimetric continuous-flow assays for blood glucose, lactate, pyruvate, alanine, glycerol and 3-hydroxybutyrate. Clin Chem 1978;24:1724-9.

${ }^{16}$ Foster KJ, Alberti KGMM, Hinks L, et al. Blood intermediary metabolites and insulin concentrations after an overnight fast: reference ranges for adults and interrelations. Clin Chem 1978;24:1568-72.

17 Assan R. La somatostatine: une nouvelle hormone ? Diabete Metab 1976; ;ه 2:135-46.

18 Felig P, Wahren J. Somatostatin and diabetes: suppression of glucose $\overrightarrow{\vec{\sigma}}$ absorption rather than stimulation of glucose disposal. Metabolism 3 $1976 ; 25: 1509-11$.

19 National Diabetes Advisory Board. A study of insulin supply and demand. Washington DC: US Department of Health, Education and Welfare, 1978. (NIH-78-1588.)

(Accepted 12 February 1981) 